\title{
LASIANCISTRUS SCOLYMUS, A NEW SPECIES OF MAILED CATFISH FROM RIO ARIPUANÃ, EST. MATO GROSSO DO SUL, BRAZIL (PISCES, SILURIFORMES, LORICARIIDAE)
}

\author{
by
}

\author{
H. NIJSSEN \& I. J. H. ISBRÜCKER \\ Institute of Taxonomic Zoology, University of Amsterdam, \\ P.O. Box 20125, $1000 \mathrm{HC}$ Amsterdam, The Netherlands
}

\begin{abstract}
Lasiancistrus scolymus $\mathrm{n}$. sp. is described and illustrated, based upon the holotype from Rio Aripuanã, Rio Madeira system, Est. Mato Grosso do Sul, Brazil. It is compared with Lasiancistrus heteracanthus (Günther, 1869), type-species of the genus Lasiancistrus Regan, 1904.

\section{RÉSUMÉ}

Lasiancistrus scolymus n. sp. est décrit et illustré, cette description étant basée sur l'holotype du Rio Aripuanã, bassin du Rio Madeira, État Mato Grosso do Sul, Brésil. La nouvelle espèce est comparée avec Lasiancistrus heteracanthus (Günther, 1869), espèce-type du genre Lasiancistrus Regan, 1904.
\end{abstract}

\section{INTRODUCTION}

The holotype and single known specimen of the species we describe here as Lasiancistrus scolymus n. sp. was found in the ichthyological collection of the Museu de Zoologia da Universidade de São Paulo (MZUSP) during a visit of the second author in January 1983.

According to Howes (1983), Lasiancistrus Regan, 1904, is a genus of the subfamily Chaetostomatinae (incorrectly spelled Chaetostominae by Howes, 1983). With the inclusion of the new species, Lasiancistrus consists of 24 species (cf. Isbrücker, 1980; Heitmans et al., 1983), several of which are not well known. After a comparison with various species (either from specimens or from data in literature), $\mathrm{La}$ siancistrus scolymus appears to us to be most closely related with the type-species of the genus, L. heteracanthus (Günther, 1869), which is known from the holotype only. We have made a direct comparison between both holotypes and feel confident that they represent two distinct species.

We are grateful to Dr. H. A. Britski (MZUSP), and to Mr. G. J. Howes (British Museum (Natural History), London, $\mathrm{BMNH}$ ) for access to the material in their care. Mr. L. A. van der Laan (Instituut voor Taxonomische Zoölogie (Zoölogisch Museum), Amsterdam, ZMA) made the photographs.

Financial support for the visit to Brazil was given to the second author by the Treub Society for Tropical Research (Utrecht), the Artis Fund (Amsterdam), and by the Royal Academy of Sciences of the Netherlands (Amsterdam).

Lasiancistrus scolymus n. sp.

(Figs. 1-3; table I-A)

Material. - Holotype, MZUSP 26809, probably a nuptial male, standard length $143.6 \mathrm{~mm}$, Brazil, Est. Mato Grosso do Sul, Rio Aripuanã, Humboldt $\left(10^{\circ} 10^{\prime} \mathrm{S}\right.$ $\left.59^{\circ} 27^{\prime} \mathrm{W}\right)$, Rio Madeira system, coll. J. G. Da Silva, 16-X-1976.

Etymology.- From the Latin scolymus, a kind of thistle; alluding to the presence of different sharp odontodes on the sides of snout and head.

Description.- Morphometric data (taken according to the methods described by Heitmans et al., 1983: 34-35, fig. 1) are given in table I. Figs. 1-3 illustrate the holotype.

Interoperculum with a clump of about 25 prominent evertible odontodes, anteriorly about $3 \mathrm{~mm}$ long, increasing gradually in size posteriorly, the longest being about $15 \mathrm{~mm}$. The odontodes are proximally embedded in a fleshy shaft, of which the thickness (on the longest odontode at the distal end of the shaft) is $0.9 \mathrm{~mm}$. These evertible odontodes are whitish, except for their tips, which are bright 


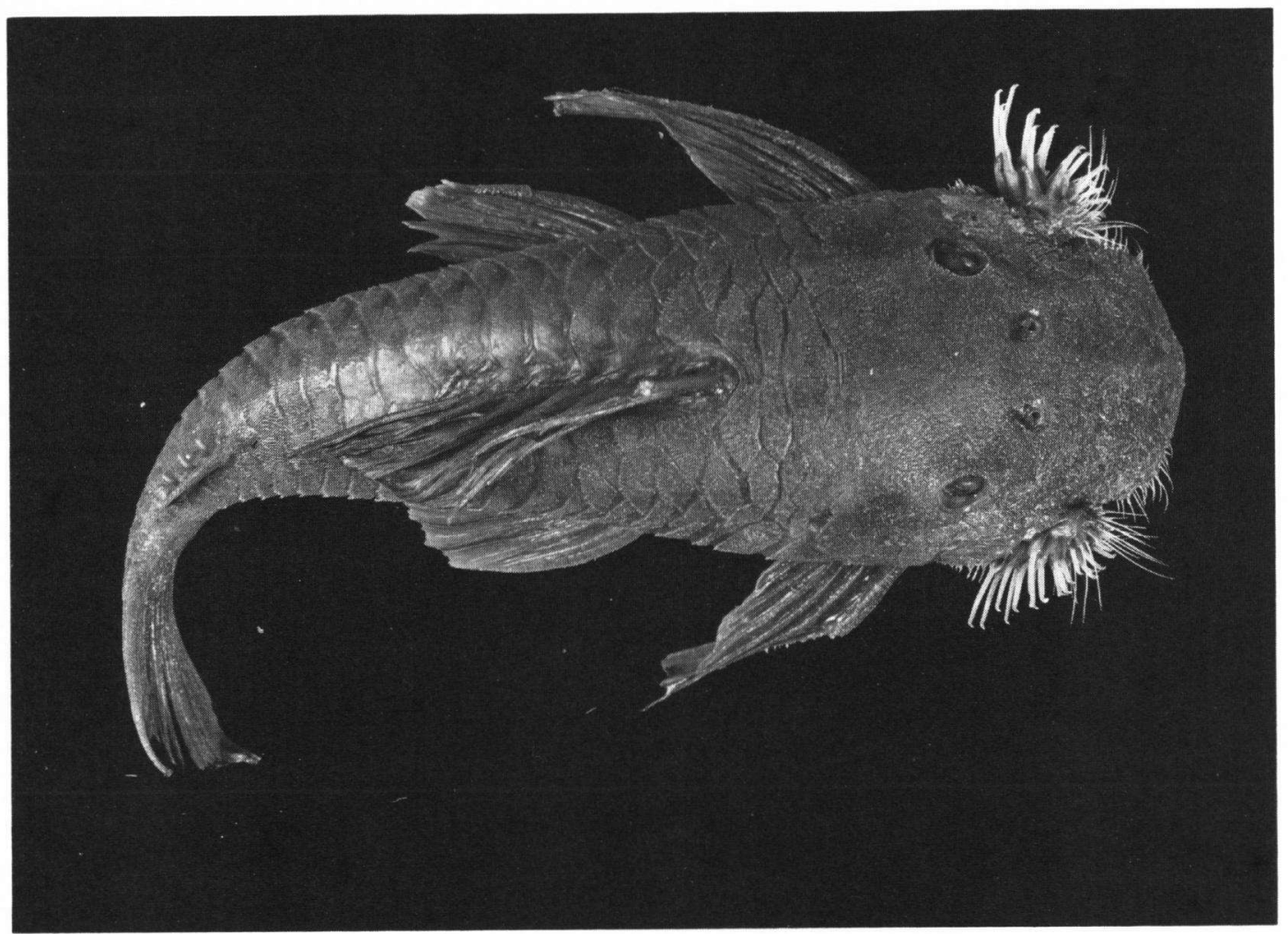

Fig. 1. Lasiancistrus scolymus n. sp., holotype in dorsal view.

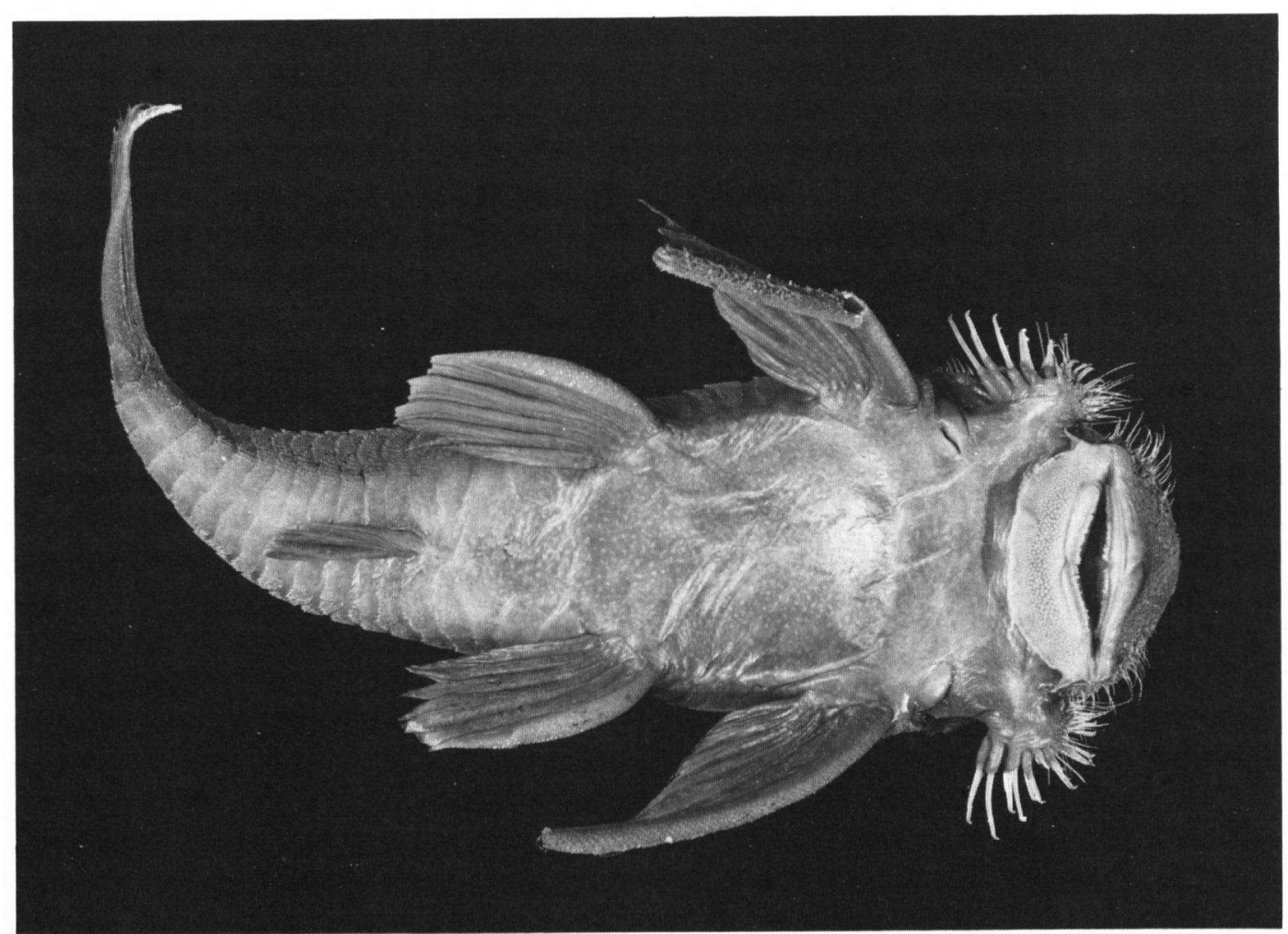

Fig. 2. Lasiancistrus scolymus n. sp., holotype in ventral view. 
yellow. The tips are sharply curved toward the anterior axis of the head, and acute distally. The clump of evertible odontodes is bordered (and partly mixed with) dorsally, anteriorly and ventrally by a series of extremely thin, often very long (stiff, hair-like) odontodes, up to about $12.5 \mathrm{~mm}$ long as measured from the distal end of the fleshy shaft. These "hairs" have various distal positions. Some curve faintly sideward, others backward, and still others bend forward; some are straight. Like the evertible odontodes, the "hairs" are whitish and have minute, acute, yellow-coloured tips which may be curved or not.

Similar, although considerably shorter hairlike odontodes are present on the sides of the snout anterior to the interopercular area, leaving a broad frontal area devoid of them. The longest of these fragile odontodes are about 5.5 $\mathrm{mm}$. The opercular margin is provided with twelve (at the right side, because of damage most are lost at the left side) thin but prominent, erect or oblique odontodes, largest of which measures $2.8 \mathrm{~mm}$.

Lateral body scutes 25, including a triangular scutelet on the caudal fin base. Small, triangular scutelets on the caudal fin base 7 (left side), 8 (right side) in vertical series. Predorsal scutelets 5 , between the supraoccipital process and the procurrent dorsal fin spinule: (a) one at either side of the supraoccipital process, (b) two large, median scutes (with a faint median suture, anteriorly reaching the supraoccipital process), (c) a median pair of more or less triangular scutes (with a faint median suture), and (d) a narrow, curved predorsal scutelet in front of the procurrent predorsal spinule. This scutelet reaches to the first of six scutes along the dorsal fin base, followed by seven scutes between the dorsal fin and the adipose fin spine (which is preceded by one azygous scutelet, having a sharp posteromedial elevation), one scute along the adipose fin spine, three scutes along the adipose fin membrane, and two scutes between this membrane and the first procurrent caudal fin spinule. These scutes - between dorsal fin spine and the caudal fin base- are dorsally flattened.
Two scutes are present along the anal fin base, and eleven between the anal fin and the procurrent caudal fin spinule. These ventral scutes are also flattened. Posteriorly they are broader than the more dorsal sides of the caudal peduncle, forming a feeble ventrolateral keel on the last five scutes. Just behind the head are five scutes at either side in transverse series.

Dorsal fin I, 6, i; anal fin I, 4, i; pectoral fin I, 6; pelvic fin I, 5; caudal fin I, 14, I. Five procurrent caudal fin spinules in front of the upper lobe, one in front of the lower lobe.

Caudal fin slightly emarginate, the lower lobe being longer than the upper.

Head and snout in front of the eyes rough, especially along the snout margin, where ossifications extend ventrally towards the narrow dorsal side of the upper lip.

Cleithrum likewise rough, the remainder of the head being smooth because of the minute odontodes. Sutures of most ossifications of the head are faintly visible, except for those on and along the snout. Body scutes with longitudinal series of prominent odontodes, those along their margins larger than the others. Dorsum of first three pectoral fin rays and of first four pelvic fin rays with prominent odontodes.

No continuous longitudinal series of prominent odontodes on the body scutes.

Supraorbital rim hardly raised. Supraoccipital posteriorly with a transversely straight and broad process.

Abdomen entirely naked. Lateral line hardly visible.

Dorsum of upper lip very narrow, naked, its margin smooth. Ventral side of this lip narrow, with a transverse series of small papillae, leaving a smooth margin in front of the teeth. The papillate part of the upper lip continues without interruption onto the lower lip. The lower lip is papillate (except for its posterior margin, which is smooth, and except for a strip near the base of the teeth); the larger papillae are those on the middle of the lip, beyond the teeth. At either side there is a small, smooth, triangular maxillary barbel.

The premaxilla is about $11 \mathrm{~mm}$, with numerous small and slender teeth. The teeth 

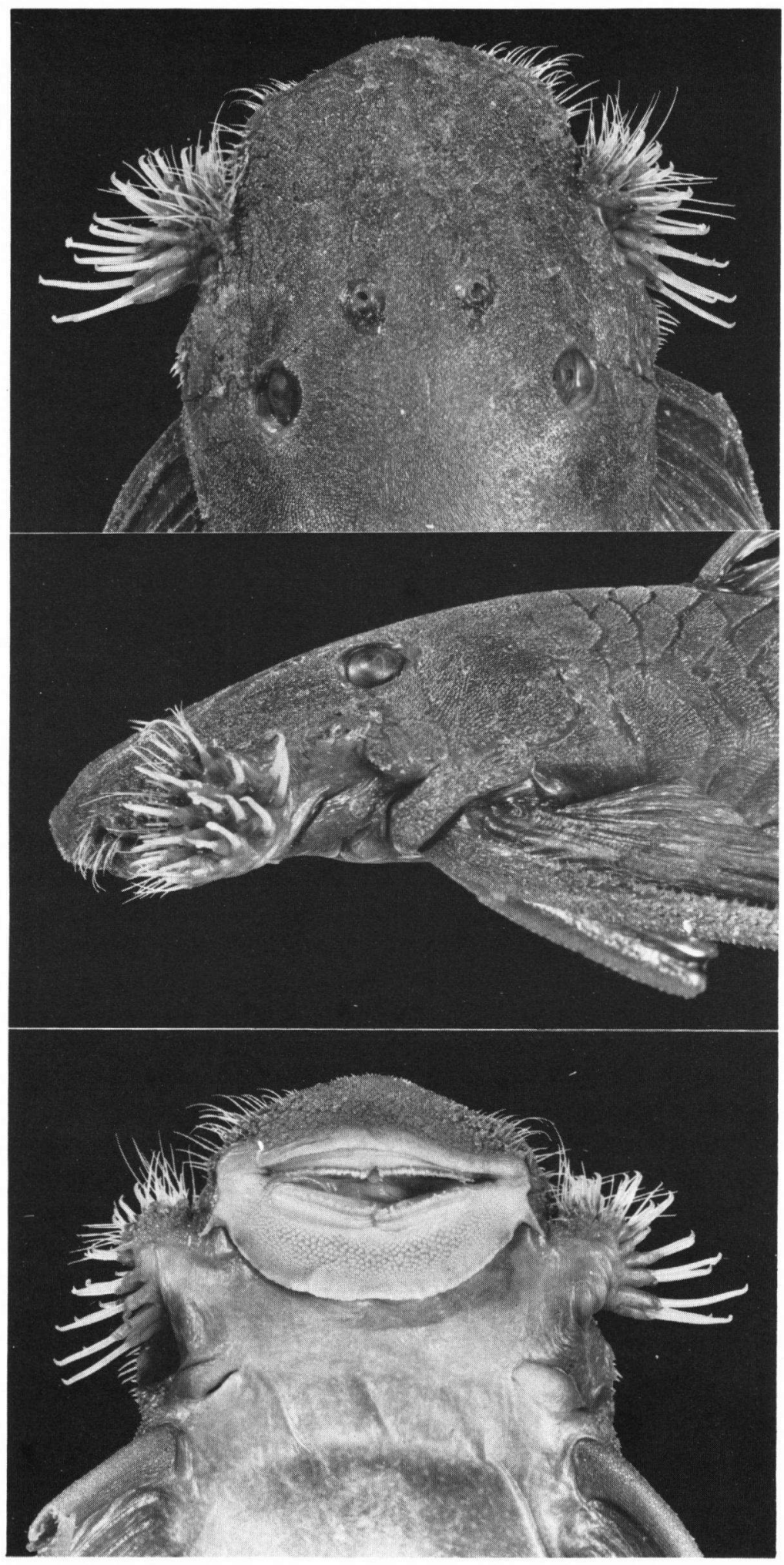

Fig. 3. Lasiancistrus scolymus n. sp., head of holotype in dorsal, lateral and ventral view. 
are arranged into an irregular, sometimes double row, which is difficult to count accurately. The crown of the premaxillary teeth is sharply bent inwards. The teeth are bifid, with a larger, truncate inner lobe and a smaller, triangular outer lobe.

The mandible is about $10 \mathrm{~mm}$ and has numerous teeth, like those in the premaxilla. The mandibular teeth have a large, elongate (rectangular to acute) inner lobe and a smaller, triangular outer lobe.

Colour in alcohol. - Ground colour of naked ventral parts reddish tan, of lips and of ventral body scutes yellowish and greyish tan, respectively. Abdomen with numerous, minute whitish, ill-defined markings.

Sides and dorsum of head and body, and the fins are brownish grey, without markings.

Comparison.- See Lasiancistrus heteracanthus, below.

Lasiancistrus heteracanthus (Günther, 1869) (Fig. 4; table I-B)

Chaetostomus heteracanthus Günther, 1869: 425-426, figs. 3-4 (original description; type-locality: "Upper Amazons" and "Peruvian Amazons"; holotype).

Material. - Holotype examined, BMNH 1869.5.21:3, probably a nuptial male, standard length $153 \mathrm{~mm}$, Peru, Upper Amazon, coll. E. Bartlett.

Comparison with Lasiancistrus scolymus. Morphometric data are given in table I. Fig. 4 is a reproduction of Günther's (1869, figs. 3-4) original illustrations.

Günther (1869: 426) stated in italics: "Interoperculum with two kinds of spines, there being a group of about twelve slender but stiff and slightly hooked spines surrounded by a ring of long setiform spines..."

Interopercular evertible, spike-like odontodes $7 \mathrm{~mm}$ long anteriorly, $17.6 \mathrm{~mm}$ posteriorly; length of interopercular evertible hair-like odontodes up to about $25 \mathrm{~mm}$. Margin of snout in front of the hair-like odontodes, and anterior surface of interoperculum, rough because of the presence of prominent odontodes.
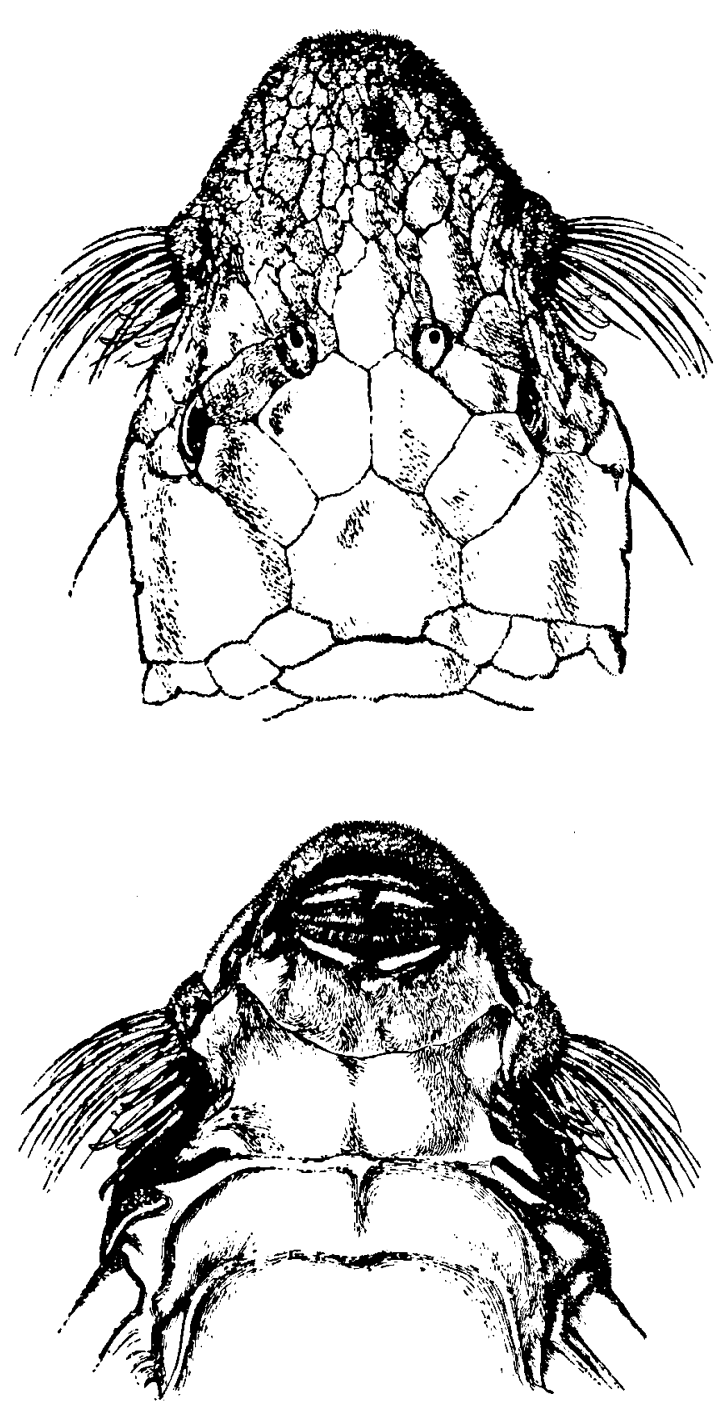

Fig. 4. Lasiancistrus heteracanthus (Günther, 1869), reproduction of Günther's original illustrations of the holotype.

Lateral body scutes 26 (left side), 27 (right side). Small, triangular scutelets on the caudal fin base 8 (both sides) in vertical series. Predorsal scutes 4 . Two scutes along the adipose fin membrane, and five between this membrane and the anterior procurrent caudal fin spinule. Number of scutes otherwise as in Lasiancistrus scolymus.

Fourth predorsal scute very small, crescentshaped, just reaching anterior margin of first scute along dorsal fin base. Mediodorsal scutes not distinctly flattened. 
TABLE I

Morphometric data of the holotype of Lasiancistrus scolymus n. sp. and those of $L$. heteracanthus (Günther, 1869), respectively. (A-B) = data in mm; $A-B=$ ratios of standard length; $A^{\prime}-B^{\prime}=$ ratios of head length.

\begin{tabular}{|c|c|c|c|c|c|c|}
\hline specimen & (A) & (B) & A & B & $\mathbf{A}^{\prime}$ & $\mathrm{B}^{\prime}$ \\
\hline mature male & + & + & & & & \\
\hline standard length & 143.6 & 153.0 & 143.6 & 153.0 & 143.6 & 153.0 \\
\hline axial length & 170.2 & - & - & - & - & - \\
\hline total length & 186.5 & - & - & - & - & - \\
\hline head length & 51.7 & 59.0 & 2.8 & 2.6 & - & - \\
\hline predorsal length & 62.7 & 70.5 & 2.3 & 2.2 & 0.8 & 0.8 \\
\hline postdorsal length & 50.8 & 52.2 & 2.8 & 2.9 & 1.0 & 1.1 \\
\hline postanal length & 41.6 & 40.1 & 3.5 & 3.8 & 1.2 & 1.5 \\
\hline dorsal fin base & 29.5 & 33.5 & 4.9 & 4.6 & 1.8 & 1.8 \\
\hline interdorsal length & 31.1 & 30.0 & 4.6 & 5.1 & 1.7 & 2.0 \\
\hline dorsal spine length & $>31.2$ & 45.1 & $<4.6$ & 3.4 & $<1.7$ & 1.3 \\
\hline anal spine length & 15.4 & 19.2 & 9.3 & 8.0 & 3.4 & 3.1 \\
\hline anal fin height & 20.3 & 22.2 & 7.1 & 6.9 & 2.6 & 2.7 \\
\hline pectoral spine length & $>47.1$ & 60.2 & $<3.1$ & 2.5 & $<1.1$ & 1.0 \\
\hline pelvic spine length & 31.0 & 39.0 & 4.6 & 3.9 & 1.7 & 1.5 \\
\hline adipose spine length & 13.1 & 7.6 & 11.0 & 20.1 & 4.0 & 7.8 \\
\hline upper caudal spine & 35.8 & - & 4.0 & - & 1.4 & - \\
\hline lower caudal spine & 42.9 & $>35.6$ & 3.4 & $<4.3$ & 1.2 & $<1.7$ \\
\hline snout length & 34.0 & 37.8 & 4.2 & 4.1 & 1.5 & 1.6 \\
\hline lower lip length & 7.7 & 9.7 & 18.7 & 15.8 & 6.7 & 6.1 \\
\hline maxillary barbel & 2.6 & 2.9 & 55.2 & 52.8 & 19.9 & 20.3 \\
\hline maxillary barbel + lip & 8.6 & 7.7 & 16.7 & 19.9 & 6.0 & 7.7 \\
\hline thoracic length & 34.2 & 36.0 & 4.2 & 4.3 & 1.5 & 1.6 \\
\hline abdominal length & 34.2 & 33.4 & 4.2 & 4.6 & 1.5 & 1.8 \\
\hline maximum orbital diameter & 7.9 & 9.3 & 18.2 & 16.5 & 6.5 & 6.3 \\
\hline interorbital length & 23.5 & 31.5 & 6.1 & 4.9 & 2.2 & 1.9 \\
\hline cleithral width & 47.1 & 50.0 & 3.1 & 3.1 & 1.1 & 1.2 \\
\hline supracleithral width & 42.2 & 48.2 & 3.4 & 3.2 & 1.2 & 1.2 \\
\hline head depth & 21.9 & 26.1 & 6.6 & 5.9 & 2.4 & 2.3 \\
\hline body depth at dorsal & 21.1 & 25.5 & 6.8 & 6.0 & 2.5 & 2.3 \\
\hline body width at dorsal & 41.5 & 41.6 & 3.5 & 3.7 & 1.3 & 1.4 \\
\hline body width at anal & 26.7 & 24.7 & 5.4 & 6.2 & 1.9 & 2.4 \\
\hline depth caudal peduncle & 15.5 & 15.9 & 9.3 & 9.6 & 3.3 & 3.7 \\
\hline width caudal peduncle & 7.9 & 6.6 & 18.2 & 23.2 & 6.5 & 8.9 \\
\hline
\end{tabular}

Dorsal fin I, 7; anal fin I, 5; formulae of pectoral, pelvic, and caudal fins as in $L$. scolymus. Distal ends of caudal fin spines and rays broken off.

Operculum very small, oval, with about six conspicuous odontodes which curve backward. Area around operculum up to orbital rim, and reaching to interopercular margin, covered with isolated dermal ossifications embedded in skin. Supraorbital margin hardly raised.
Interorbital through supraoccipital area rather smooth, cleithrum slightly rougher. Supracleithral margin damaged at right side.

Pectoral fin with short, thorn-like odontodes. Anterior half of dorsum of first pectoral fin ray with prominent odontodes.

Abdomen with numerous minute dermal ossifications bearing odontodes, the ossifications being widely scattered at the height of the pelvic fin bases, gradually becoming more 
numerous anteriorly, reaching to the anteroventral margin of the cleithrum.

Dorsum of upper lip rough, almost completely (viz., except for its margin) covered with ossifications bearing conspicuous odontodes.

Orbital rim with a small posterior notch.

The premaxilla as well as the mandible are 8 $\mathrm{mm}$. Teeth numerous, long and very slender; in more than one row, being difficult to count accurately. The crown of the inner tooth lobe is quite large and either truncate or acute distally, whereas the crown of the outer lobe is much smaller and triangular.

Colour. - The holotype is now completely faded. Günther (1869: 426) described the colour as: "Uniform greyish; each dorsal scute lighter in the centre." Regan (1904: 237) described the colour pattern of the same specimen as follows: "Olivaceous; a blackish spot at the base of the first dorsal ray."

Main differences between Lasiancistrus heteracanthus and $L$. scolymus. -

(a) Morphometric characters (table I): head length, postanal length, interdorsal length, dorsal-, anal-, pelvic-, and adipose fin spine length, abdominal length, orbital diameter, interorbital width, head depth, body depth at dorsal fin origin, body width at anal fin origin, and depth and width of caudal peduncle.

(b) Meristic characters: number of lateral body scutes, predorsal scutes, scutes between adipose fin spine and origin of caudal fin, and number of interopercular odontodes. In $L$. heteracanthus the last ray of dorsal- and anal fin is not split, whereas these rays are split to the base in $L$. scolymus.

(c) L. heteracanthus has dermal ossifications on the abdomen, which are absent on the abdomen of $L$. scolymus. The respective holotypes differ only $9.4 \mathrm{~mm}$ in standard length.

The size and number of interopercular odontodes is strikingly different in both species. Since each species is known from a single specimen only, it is uncertain whether these differences are due to the stage of development of a secondary sexual character or indicative of a species distinction.

\section{REFERENCES}

Günther, A. [C. L. G.], 1869. Descriptions of some species of fishes from the Peruvian Amazons. Proc. zool. Soc. London, 1869: 423-429.

Heitmans, W. R. B., H. Nijssen \& I. J. H. Isbrücker, 1983. The mailed catfish genus Lasiancistrus Regan, 1904, from French Guiana and Surinam, with descriptions of two new species (Pisces, Siluriformes, Loricariidae). Bijdr. Dierk., 53 (1): 33-48.

Howes, G. J., 1983. The cranial muscles of loricarioid catfishes, their homologies and value as taxonomic characters (Teleostei: Siluroidei). Bull. Br. Mus. nat. Hist. (Zool.), 45 (6): 309-345.

IsBRÜCKER, I. J. H., 1980. Classification and catalogue of the mailed Loricariidae (Pisces, Siluriformes). Verslagen en technische Gegevens, Inst. taxon. Zoöl. (Zoöl. Mus.), Univ. Amsterdam, 22: 1-181.

Regan, C. T., 1904. A monograph of the fishes of the family Loricariidae. Trans. zool. Soc. London, 17 (3): 191-350, pls. IX-XXI. 